\title{
A Patriot for Whom? The Afterlives of Bolingbroke's Patriot King
}

\section{Citation}

Armitage, David. 1997. A patriot for whom? The afterlives of Bolingbroke's Patriot King. Journal of British Studies 36(4): 397-418.

\section{Published Version}

http://dx.doi.org/10.1086/386143

\section{Permanent link}

http://nrs.harvard.edu/urn-3:HUL.InstRepos:3373616

\section{Terms of Use}

This article was downloaded from Harvard University's DASH repository, and is made available under the terms and conditions applicable to Other Posted Material, as set forth at http:// nrs.harvard.edu/urn-3:HUL.InstRepos:dash.current.terms-of-use\#LAA

\section{Share Your Story}

The Harvard community has made this article openly available.

Please share how this access benefits you. Submit a story.

\section{Accessibility}




\title{
A Patriot for Whom? The Afterlives of Bolingbroke's Patriot King
}

\author{
David Armitage
}

The transformation of patriotism into nationalism has become one of the accepted grand narratives of eighteenth-century British history. ${ }^{1}$ From its first appearance in English in the 1720s, "patriotism" as a political slogan expressed devotion to the common good of the patria and hostility to sectional interests and became a staple of oppositional politics. Though it was attacked by ministerialist writers, it was a liability only for those like the elder Pitt, whose attachment to patriotism when in opposition was not matched by his behavior when in government. ${ }^{2}$ However, the Wilkesite agitations and the debate over the American War decisively tainted patriotism with the whiff of factious reformism, and it was in just this context, in 1775, that Dr. Samuel Johnson famously redefined patriotism as "the last refuge of a scoundrel." ${ }^{3}$ In the following

David ARmitage is associate professor of history at Columbia University. Earlier versions of this article were presented at the North American Conference on British Studies in Vancouver, at the Seminar on British Studies since the Reformation at Princeton University, and at the Columbia University Seminar on Eighteenth-Century European Culture. I am particularly grateful to Guido Abbattista, Tony Davies, Margot Finn, Lige Gould, Philip Harling, Peter Lake, and Dror Wahrman for their comments and assistance.

${ }^{1}$ See, e.g., Linda Colley, "The Apotheosis of George III: Loyalty, Royalty and the British Nation, 1760-1820,' Past and Present, no. 102 (1984): 94-129; John Dinwiddy, "England,' in Nationalism in the Age of the French Revolution, ed. Otto Dann and John Dinwiddy (London, 1988), pp. 53-70; Paul Langford, A Polite and Commercial People: England, 1727-1783 (Oxford, 1989), p. 6; Hugh Cunningham, "The Language of Patriotism," in Patriotism: The Making and Unmaking of British National Identity, vol. 1, History and Politics, ed. Raphael Samuel (London, 1989), pp. 57-66; and David Eastwood, "Robert Southey and the Meanings of Patriotism," Journal of British Studies 31 (1992): 265-71. For nuanced correctives to this orthodoxy, see Philip Harling, "The Duke of York Affair (1809) and the Complexities of War-Time Patriotism," Historical Journal 39 (1996): 963-84; and Eliga H. Gould, "American Independence and Britain's Counterrevolution," Past and Present, no. 154 (1997): 107-41.

${ }^{2}$ John Brewer, Party Ideology and Popular Politics at the Accession of George III (Cambridge, 1976), pp. 96-111; Marie Peters, Pitt and Popularity: The Patriot Minister and London Opposition during the Seven Years' War (Oxford, 1980).

${ }^{3}$ John Sainsbury, Disaffected Patriots: London Supporters of Revolutionary America, 1769-1782 (Kingston, Ontario, 1982), pp. 127-31.

Journal of British Studies 36 (October 1997): 397-418

(C) 1997 by The North American Conference on British Studies.

All rights reserved. 0021-9371/97/3604-0002\$02.00 
half century, both radicals and loyalists fought over the appropriation of patriotism: the radicals to rescue it from the contempt into which it had fallen in the 1770s, the loyalists and the government to harness its potent discourse of national duty for the cause of monarchical revivalism and aggressive anti-Gallicanism. It is now generally agreed that the conservatives won, as the oppositional language of the early and mid-eighteenth century was thereby transformed into "an officially constructed patriotism which stressed attachment to the monarchy, the importance of empire, the value of military and naval achievement, and the desirability of strong, stable government by a virtuous, able and authentically British elite." ${ }^{4}$ This new-forged patriotism, aggressive, anticosmopolitan, and particularist, provided the foundation for later nationalism and jingoism. Patriotism's republican and radical heritage was long since forgotten by the heyday of empire in the nineteenth century and has only recently been recovered by a salutary effort of intellectual archaeology. ${ }^{5}$

The transmission of the language of patriotism has attracted less attention than its transformation. From its entry into British political language in the 1720s, patriotism formed part of the longer Country tradition, as it was transmitted from Exclusionist England to Revolutionary America ${ }^{6}$ The gradual appropriation of patriotism by conservatives and loyalists would seem to belie the continuity of the reformist tradition of which it was a part. Recent historians have remarked on the fact that late eighteenth- and nineteenth-century radicalism drew on long-accumulated traditions of patriotism that had their origins in the "highly conservative ideology of the Country party tradition." This has been taken to reflect the eclecticism of radicals, who drew as freely on traditional constitutionalism, patriotism, and parliamentarism as they did on Paineite republicanp. 145 .

${ }^{4}$ Linda Colley, Britons: Forging the Nation, 1707-1837 (New Haven, Conn., 1992),

${ }^{5}$ Cunningham, "The Language of Patriotism," pp. 70-82. For a more general account of the European context in which "republican" patriotism was transformed into nineteenth-century nationalism, see Maurizio Viroli, For Love of Country: An Essay on Patriotism and Nationalism (Oxford, 1995).

${ }^{6}$ On its transmission, see the classic works of Caroline Robbins, The EighteenthCentury Commonwealthman: Studies in the Transmission, Development and Circumstance of English Liberal Thought from the Restoration of Charles II until the War with the Thirteen Colonies (Cambridge, Mass., 1959); Bernard Bailyn, The Ideological Origins of the American Revolution (1967; rev. ed., Cambridge, Mass., 1992); Quentin Skinner, "The Principles and Practice of Opposition: The Case of Bolingbroke versus Walpole," in Historical Perspectives: Studies in English Thought and Society in Honour of J. H. Plumb, ed. Neil McKendrick (London, 1974), pp. 113-21; and J. G. A. Pocock, The Machiavellian Moment: Florentine Political Thought and the Atlantic Republican Tradition (Princeton, N.J., 1975). 
ism. ${ }^{7}$ The connection between the narratives of the rightward drift of patriotism and the continuity of the radical tradition across the eighteenth century $^{8}$ compels a reconsideration of the supposed conservatism of the Country tradition itself and demands a reassessment of the figure who stands most often as a synecdoche for that tradition, Henry St. John, Viscount Bolingbroke. ${ }^{9}$ This article will therefore examine the reception of Bolingbroke's The Idea of a Patriot King (1738) in order to show how one version of early eighteenth-century patriotism retained its links with radicalism up to the 1780 s, resisted appropriation by monarchical reaction in the following three decades, and only finally succumbed to conservatism in the aftermath of Reform in the 1830s.

The most influential reading of Bolingbroke and his intellectual heritage has been that associated with Isaac Kramnick. ${ }^{10}$ In his account, Bolingbroke became the key spokesman for a nostalgic, and fundamentally antimodern, country ideology, which was hostile to a shift away from consensual aristocratic politics and an agrarian economy and toward party government and the burgeoning growth of a fiscal-military state based on public credit and insecure financial institutions. As the effusions of a disaffected scion of the Wiltshire squirearchy, Bolingbroke's political views could "be seen as products of his social existence, of his position in the group life of Augustan England, in terms both of economic class and occupational group": in short, as an ideology in the Marxistreductionist sense. ${ }^{11}$ This reading has become an almost entirely unquestioned orthodoxy in eighteenth-century studies, despite its shortcomings as biography, as an accurate account of a more variegated discourse, or as a description of an ideology that was urban as well as rural, "bourgeois" as well as aristocratic, and radical precisely because it was back-

${ }^{7}$ Margot C. Finn, After Chartism: Class and Nation in English Radical Politics, 1848-1874 (Cambridge, 1993), pp. 14, quote on p. 51; James A. Epstein, "The Constitutionalist Idiom," in his Radical Expression: Political Language, Ritual, and Symbol in England, 1790-1850 (New York, 1994), pp. 3-28.

${ }^{8}$ J. G. A. Pocock, "The Varieties of Whiggism from Exclusion to Reform: A History of Ideology and Discourse,' in his Virtue, Commerce, and History: Essays on Political Thought, Chiefly Eighteenth Century (Cambridge, 1985), pp. 215-310, presents a more richly inflected account of the continuities than Robert Zaller, "The Continuity of British Radicalism in the Seventeenth and Eighteenth Centuries," Eighteenth-Century Life 6 (1981): 17-38.

${ }_{9}^{9}$ Compare Carla H. Hay, James Burgh: Spokesman for Reform in Hanoverian England (Washington, D.C., 1979), p. 104, where she remarks " just how innately conservative the radical movement was" and recognizes in this context that "there is a need for further research to determine the pervasiveness of the patriot king theme."

${ }^{10}$ Isaac Kramnick, Bolingbroke and His Circle: The Politics of Nostalgia in the Age of Walpole (1968; reprint, Ithaca, N.Y., 1992).

${ }^{11}$ Ibid., p. 3. 
ward looking. ${ }^{12}$ It almost completely overlooks The Idea of a Patriot King, which Kramnick takes to be discontinuous with Bolingbroke's more characteristic populist and constitutionalist diagnoses of the state of Britain: "its humanist solution . . . futile before the inexorable economic and political developments that he himself had so ably described." 13 This neglect has created an unbalanced account of Bolingbroke's political thought: in effect, Hamlet without the prince.

The Idea of a Patriot King is at once among the most famous and the most maligned works of eighteenth-century British political thought. Even for Bolingbroke's most committed students, the work is "a confession of failure," neither his "greatest" nor his "most influential political treatise," and its importance is "undoubtedly exaggerated" by its opponents. It "has received attention disproportionate to its intrinsic value" and as "political philosophy ... is disappointingly superficial"; though it stands as "the summation of his political writings and career," it nevertheless "constitutes his great failure." ${ }^{14}$ Despite valuable recent contextualizations of the work in the diverse milieux of the opposition to Sir Robert Walpole, ${ }^{15}$ this consensus of disapproval has kept The Idea of a Patriot King out of studies of British patriotism in the later eighteenth century. Since Bolingbroke's politics have been assumed to be reactionary and aristocratic, they have been taken to be irrelevant to later traditions that were radical and demotic, and he is remembered rather as the grandfather of English conservatism, the forerunner of Edmund Burke, the model for Benjamin Disraeli, and the totem for the Tory party of Rab Butler. ${ }^{16}$ Where the Patriot King appears at all, it is as a plank in this conservative platform, with the Dissertation upon Parties as the key text from a supposedly more radical and populist Bolingbroke. Yet the Patriot King proved equally popular with radicals in the contention

${ }^{12}$ Though for trenchant counterblasts, see Pocock, "The Varieties of Whiggism from Exclusion to Reform,'” pp. 242, 259, 261-62.

${ }^{13}$ Kramnick, Bolingbroke and His Circle, p. 167.

${ }^{14}$ H. T. Dickinson, "Bolingbroke: The Idea of a Patriot King," History Today 20, no. 1 (January 1970): 13, 18, 19, and Bolingbroke (London, 1970), p. 307; Simon Varey, Henry St. John, Viscount Bolingbroke (Boston, 1984), p. 98; Kramnick, Bolingbroke and His Circle, pp. 163, 167.

${ }^{15}$ J. C. D. Clark, English Society, 1688-1832 (Cambridge, 1985), pp. 179-85; Christine Gerrard, The Patriot Opposition to Walpole: Politics, Poetry, and National Myth, 1725-1742 (Oxford, 1994), chap. 7.

${ }^{16}$ Sir Geoffrey Butler, The Tory Tradition: Bolingbroke, Burke, Disraeli, Salisbury (1914), preface by R. A. Butler (London, 1957), chap. 1; Sydney Jackman, Man of Mercury: An Appreciation of the Mind of Henry St. John, Viscount Bolingbroke (London, 1965), pp. 140-46; Harvey Mansfield, Jr., Statesmanship and Party Government: A Study of Burke and Bolingbroke (Chicago, 1965); Richard Faber, Beaconsfield and Bolingbroke (London, 1961). 
over the American War, the Association Movement, and the Reform controversy. Only once Reform had been achieved did Bolingbroke's patriot king come to stand as the emblem of an archaic and nostalgic ideal, and only then did Bolingbroke join the ranks of reactionaries, to become a founding father of Toryism.

The Idea of a Patriot King was the last major example in the English-speaking world of that venerable humanistic genre, the mirror for a prince. ${ }^{17}$ Exactly which prince was to be the recipient of Bolingbroke's counsel cannot be settled for certain, though Frederick Louis, Prince of Wales, is a much more plausible candidate than Charles Edward Stuart. ${ }^{18}$ Its composition may also have been spurred by the birth of Frederick's son, Prince George, later to be George III, in June $1738 .{ }^{19}$ Bolingbroke had returned to England from exile in France in July 1738, just a month after the infant prince was born, and composed his work in the autumn of that year. The birth of Frederick's son gave hope for dynastic continuity and thereby strengthened the hand of the Prince of Wales, not least by adding further paternal domesticity to his image in order to erase the public's memories of his misspent youth. ${ }^{20}$ It was also at this point that Frederick was moving nearer to the leaders of the opposition to Walpole and was openly flaunting his connections with the enemies of his father's chief minister. Yet even those closest to Frederick realized his instability and political weakness. In such a situation, and at such a time, the need arose for counsel from a wise and experienced adviser. In February, Bolingbroke had already adverted to the necessity of making a prince into

${ }^{17}$ On the Patriot King and the mirror-for-princes genre, see Jeffrey Hart, Viscount Bolingbroke: Tory Humanist (London, 1965), pp. 83-116; and Gerrard, The Patriot Opposition to Walpole, pp. 198-203. For other contemporary instances, see Daniel Defoe, Of Royall Educacion (ca. 1728), ed. Karl D. Bülbring (London, 1895); Andrew Michael Ramsay, A Plan of Education for a Young Prince (London, 1732), An Essay on Civil Government (ca. 1738-39; London, 1743), pp. 59-96; and Jean-Jacques Duguet, L'institution d' un prince (Paris, 1739), published in English as The Institution of a Prince: Or, A Treatise on the Qualities, Vertues and Duties of a Sovereign, 2 vols. (London, 1740), extracts from which were printed in Gentleman's Magazine 10 (1740): 54-6, 291-93 (as noted by Gerrard, p. 203, though without the attribution to Duguet).

${ }^{18}$ Simon Varey, "Hanover, Stuart, and the Patriot King," British Journal of Eighteenth-Century Studies 6 (1983): 163-72. The presence of an anti-Jacobite polemic in Pope's edition of The Idea of a Patriot King, which was retained in Bolingbroke's 1749 edition, is evidence against Varey's argument (Varey, p. 167); Bolingbroke, The Idea of a Patriot King: With Respect to the Constitution of Great Britain, ed. Alexander Pope (London, n.d.), pp. 97-101.

${ }^{19}$ For whom Frederick later wrote his own brief advice, "Instructions for My Son George, Drawn by My-Self, for His Good, That of My Family, and for That of His People, according to the Ideas of My Grand-Father, and Best Friend, George I,' 13 January 1749, printed in George Young, Poor Fred: The People's Prince (Oxford, 1937), pp. 172-75, on which, see also John Brooke, King George III (London, 1972), pp. 20-21.

${ }^{20}$ Colley, Britons, p. 206. 
an incorruptible patriot who would return the constitution to its original purity, and in October of the same year, Frederick's secretary (the opposition politician George Lyttelton) wrote to Bolingbroke's closest friend in England, Alexander Pope, urging him to help the opposition cause and to "Animate [Frederick] to . . . the Virtue least known to Princes .. . Love of the Publick." "21 Though Pope presented Lord Bathurst with advice for an adviser - "a Letter of Instruction, in what manner a Great Man should treat a Prince"'-in just this period, this hardly seems to have been what Lyttelton had in mind. It is therefore likely that Pope passed on the task of counseling Frederick to Bolingbroke, who was his houseguest at the time, and that The Idea of a Patriot King was the resulting mirror for the Prince of Wales, addressed to Lyttelton himself. ${ }^{22}$

The Patriot King has always excited more interest in its creation than in its reception, largely because of the furor over its transformation from coterie text to public work. ${ }^{23}$ Bolingbroke returned to France in the spring of 1739 and left his manuscript in the hands of Pope with express instructions that a tiny edition of fewer than ten copies should be produced for the small circle of Bolingbroke's friends in the patriot opposition to Walpole who were also close to Prince Frederick. Though the story of Pope's failure to observe Bolingbroke's wishes is a tangled one, it seems that he secretly had printed an edition of fifteen hundred copies of the book, which were found on his death and immediately burned on Bolingbroke's orders. ${ }^{24}$ Some copies survived the fire, and parts of the

${ }^{21}$ Bolingbroke to Sir William Wyndham, 3 February 1738, cited in Brean S. Hammond, Pope and Bolingbroke: A Study in Friendship and Influence (Columbia, Mo., 1984), pp. 99-100; Lyttelton to Pope, 25 October [1738], in Correspondence of Alexander Pope, vol. 4, 1736-1744, ed. George Sherburn (Oxford, 1956), pp. 138-39.

${ }^{22}$ Pope to Lyttelton, [ca. 1 November 1738], in Sherburn, ed., Correspondence of Alexander Pope, 4:142; Memoirs and Correspondence of George, Lord Lyttelton, 2 vols., ed. R. J. Phillimore (London, 1845), 2:428. When Bolingbroke published the work in 1749, Lyttelton wanted all evidence of his connection to The Idea of a Patriot King removed. See Lyttelton to Bolingbroke, 4 April 1749, British Library (BL), London, Additional MS 4948a, fol. 442r.

${ }^{23}$ Fanny E. Ratchford, "Pope and the Patriot King," Texas Studies in English 6 (1926): 157-77; Giles Barber, "Bolingbroke, Pope and the Patriot King," Library 19 (1964): 67-89; Frank T. Smallwood, "Bolingbroke vs. Alexander Pope: The Publication of the Patriot King," Papers of the Bibliographical Society of America 65 (1971): 22541.

${ }^{24}$ D. J. McLaverty, Pope's Printer, John Wright: A Preliminary Study, Oxford Bibliographical Society Occasional Publication, vol. 11 (Oxford, 1977), p. 27, item 147, suggests 1741 as the date of Pope's edition. The four surviving copies of Pope's edition of The Idea of a Patriot King - in different states of completeness - are in the British Library; the Beinecke Library (Yale University); the Harry Ransom Humanities Center (University of Texas, Austin); and the Robert H. Taylor Collection, Firestone Library (Princeton University). For further details on the text, see Bolingbroke: Political Writings, ed. David Armitage (Cambridge, 1997), pp. xli-xliv. 
text drawn from one of these copies began to appear in the press in January 1749. Bolingbroke was mortified and forced to go public with both the full, revised text of the work as well as with his anger at Pope's infidelity. The ensuing pamphlet skirmish, in which Pope's executors and admirers defended his reputation against Bolingbroke's chagrin, is one of the literary causes célèbres of the eighteenth century but has little connection with the ideological legacy of patriot kingship. ${ }^{25}$ However, the violence of the controversy and the tortured circumstances in which the Patriot King first came into general circulation have overshadowed serious investigation of that legacy.

Bolingbroke's choice of the patriot king as a hero who would rise above party and defend the constitution at home and British trade abroad summed up a decade of early Hanoverian princely panegyric and oppositional poetry. ${ }^{26}$ The Patriot King's implicit satire on the oligarchical and pusillanimous regime of late Walpolean Britain as well as its ambitiously unspecific plans for moral reform and commercial prosperity also mark it as a utopian work. ${ }^{27}$ Like many such utopias, it had an immediate polemical and reformative purpose, but its lack of precise reference also made it applicable as a model for later princes and a yardstick against which to measure their conduct. The Patriot King epitomized the genre of princely advice in eighteenth-century Britain, but it did not therefore signal the desperate exhaustion of Bolingbroke's own political cause as he retreated into archaic and impractical Platonic speculation..$^{28}$ Rather, it marked a shift in Bolingbroke's presumed audience, after his years of campaigning against Walpole's administration in Parliament and the press. In his periodical essays, he had tried to shape public opinion toward a patriotic conception of the common good, and in the Senecan letters of the mid-1730s, which he wrote from France to his aristocratic allies in England, he had urged the leadership of an aristocracy of reason to revive "the spirit of patriotism." ${ }^{29}$ Though the Patriot King was writ-

${ }^{25}$ See [Bolingbroke], A Familiar Epistle to the Most Impudent Man Living (London, 1749); [William Warburton], A Letter to the Editor of the Letters on the Spirit of Patriotism, the Idea of a Patriot-King, and the State of Parties, \&c. (London, 1749).

${ }^{26}$ Gerrard, The Patriot Opposition to Walpole, pp. 208-12, decisively challenges the influential argument of Mabel Hessler Cable, "The Idea of a Patriot King in the Propaganda of the Opposition to Walpole," Philological Quarterly 18 (1939): 124-30, that Bolingbroke was the inspirer, rather than the inheritor, of these earlier images of patriot kingship.

${ }^{27}$ Hammond, Pope and Bolingbroke, pp. 139-41.

${ }^{28}$ As argued, e.g., in Dickinson, "Bolingbroke: The Idea of a Patriot King"; and Kramnick, Bolingbroke and His Circle, pp. 168-69.

${ }^{29}$ For this reading of Bolingbroke's political thought from 1733-38, see David Armitage's "Introduction," in Bolingbroke: Political Writings, pp. vii-xxiv, and the texts of the Dissertation upon Parties and the letter "On the Spirit of Patriotism" therein. 
ten as a private work for the prince and his circle, its longevity and popularity beyond its particular moment showed that he had created an advice book to top all advice books as part of what one of his eighteenthcentury editors called a "perfect system of practical politics." ${ }^{30}$ Almost all subsequent British mirrors for a prince were indebted to it, and its prescriptions became a mainstay of patriotic rhetoric, radical polemic, and conservative countercharge.

The chief sources for Bolingbroke's portrait of the patriot king were Cicero's De Officiis and Francis Bacon's De Augmentis Scientiarum. Cicero-along with the elder Cato-was one of the most contested figures in contemporary political debate, whether as the self-sacrificing exemplar of attachment to the res publica or as the trimming hypocrite whose forensic rhetoric and Stoic philosophy of service to the commonwealth masked the compromises of his political career. ${ }^{31}$ Two years earlier, in his letter "On the Spirit of Patriotism,'” Bolingbroke had joined Cicero's supporters and proclaimed the importance of his learning and experience to the service he had rendered his country, the heroism of his stand against the corruption of the late Republic, and his success in uniting "by skill and management, in the common cause of their country, orders of men the most averse to each other." ${ }^{32}$ Cicero had been a mainstay of earlier advice books, so much so that satire of De Officiis was prominent in Machiavelli's Principe, the source most often cited for Bolingbroke's work. ${ }^{33}$ Bacon supplied Bolingbroke with the work's concluding vision of the enemy of modern reason of state, "a king possessed of absolute power, neither usurped by fraud, nor maintained by force, but

${ }^{30}$ Bolingbroke, Letters on the Spirit of Patriotism: On the Idea of a Patriot King: And on the State of Parties at the Accession of King George the First, ed. T. Davies (London, 1775), p. xi (this edition was dedicated to Edmund Burke). See the response of one reader to the first edition of the Letters in 1749: "surely a finer system of Politicks without Party, was never offer'd to the World"' (Smart Lethieullier to William Borlase, 25 May 1749, BL, Stowe MS 752, fol. 28r).

${ }^{31}$ For the contemporary debate surrounding the figure of Cicero, see, e.g., [George Lyttelton], Observations on the Life of Cicero (London, 1733); and Conyers Middleton, The History of the Life of Marcus Tullius Cicero, 3 vols. (London, 1742). On the debate, see esp. Addison Ward, “The Tory View of Roman History," Studies in English Literature 4 (1964): 413-56; Reed Browning, Political and Constitutional Ideas of the Court Whigs (Baton Rouge, La., 1982), pp. 210-56; and Peter N. Miller, Defining the Common Good: Empire, Religion and Philosophy in Eighteenth-Century Britain (Cambridge, 1994), pp. 89-95.

32 Bolingbroke, "On the Spirit of Patriotism”' (1736), p. 214.

${ }^{33}$ See, e.g., Marcia Colish, "Cicero's De Officiis and Machiavelli's Prince," Sixteenth-Century Journal 9 (1978): 81-94; and the notes to James VI's Basilikon Doron (1599), in James VI and I: Political Writings, ed. Johann P. Sommerville (Cambridge, 1994). On Machiavelli and the Patriot King, see Herbert Butterfield, The Statecraft of Machiavelli (London, 1962), pp. 111-22; and Kramnick, Bolingbroke and His Circle, pp. 163-69. 
the genuine effect of esteem, of confidence, and affection" and who could be praised with tributes drawn from the greatest poetic panegyrist of imperial mission, Virgil, and from Tacitus, the harshest classical critic of courts. ${ }^{34}$

The Idea of a Patriot King was therefore a late humanist work projected into the world of Walpolean oligarchy. ${ }^{35}$ Like Van Dyck's triple portrait of Charles I, it showed three faces of the king: the unimpeachable enemy of corruption, the father of his country, and the leader of a polite and commercial people. "A Patriot King is the most powerful of all reformers," Bolingbroke asserted, and corruption-that is, the substitution of private interest for the public good-would "cease as soon as a Patriot King is raised to the throne." He would begin ruling once he began to reign, purge his court, and renew the spirit of liberty by a clean sweep of ministerial self-interest. He should then act as a nonpartisan patriarch above party, for " to espouse no party, but to govern like the common father of his people, is so essential to the character of a Patriot King, that he who does otherwise, forfeits the title.' At the head of a free people, and a reformed constitution, the patriot king could be the benign superintendent of a flourishing commercial empire, "bringing home wealth by the returns of industry; carrying assistance or terror abroad by the direction of wisdom; and asserting triumphantly the right and honour of Great Britain, as far as waters can roll and as winds can waft them.," ${ }^{36}$ All three of these faces of patriot kingship - as the panacea for corruption, the solvent of party division, and the herald of commercial greatness - were to be recalled and elaborated in the century after Bolingbroke first produced his private advice for the biddable young prince Frederick.

The Idea of a Patriot King was reprinted four times in the latter half of the century $(1752,1767,1775,1783)$ among Bolingbroke's letters on the spirit of patriotism, on the patriot king, and on the state of parties

${ }^{34}$ In The Idea of a Patriot King, in Armitage, ed., Bolingbroke: Political Writings, pp. 273, 293, Bolingbroke cites Francis Bacon, De Dignitate et Augmentis Scientiarum (1623) 1.1, in Francisci Baconis . . O Opera Omnia, 4 vols., ed. John Blackbourne (London, 1730), 1:32 (Bolingbroke was one of the subscribers of this edition; the italic number indicates the second row of pagination within the volume); Virgil, Georgics 4.561-62 (cited in Bacon, Opera Omnia, 1:56); and Tacitus, Agricola 3.2 (cited in Francis Bacon, Advancement of Learning, in Opera Omnia, 2:439). I am greatly indebted to Guido Abbattista for first drawing attention to Bolingbroke's use of Bacon in the notes to his Italian edition and translation of Bolingbroke's L'idea di un re patriota (Rome, 1995) and for generously supplying me with a draft of his work in advance of publication.

${ }^{35}$ The best treatment of Bolingbroke in a late humanist context is Philip Hicks, "Bolingbroke, Clarendon and the Role of the Classical Historian," Eighteenth-Century Studies 20 (1987): 445-71.

${ }^{36}$ The Idea of a Patriot King, in Armitage, ed., Bolingbroke: Political Writings, pp. 251, 257, 294. 
at the accession of George I. Translations also appeared in German (1765) and French (two in 1750 and one at the height of the attempts to fashion a constitutional monarchy in 1790). ${ }^{37}$ Two further English editions, in 1775 and 1831, transformed the patriot king into a supporter of conciliation with America and of parliamentary reform and projected Bolingbroke's vision of kingship into the age of the democratic revolution. ${ }^{38}$ The generalized application of the idea of patriot kingship was applied to both past, present, and even future kings in the years after Bolingbroke's death in 1751. For example, Edward Lewis's The Patriot King Displayed (1769) painted Henry VIII (somewhat implausibly) as "a tender husband,- - and indulgent father,- - a faithful friend,- a generous master, - not lewd, not cruel, not voluptuous, - an honest, open-hearted man,- - a sincere christian, and a PATRIOT KING" who had cooperated throughout his reign with his parliaments. ${ }^{39}$ Charles Churchill applied the ideal to George III in the early years of his reign as he called on the patriot king's paternalism "To make corruption dread to shew her face, / To bid affected Virtue take new state." ${ }^{40}$ Bolingbroke's vision of kingship also survived in later eighteenth-century British utopian writings such as The Reign of George VI (1763), which imagined a grand imperial monarchy with a British Versailles at the center of a set of territories comprising the new British Empire in the Americas and the old Angevin Empire in Europe: "happy for France, that it was conquered by such a patriot king!" crowed the exultant author. ${ }^{41}$

The very lack of specificity in Bolingbroke's description of the patriot king made it perennially applicable. This was especially true in a monarchical culture, in which counsel-in the sense of informed advice tending toward decisive political action-remained a central cause of political anxiety. ${ }^{42}$ This is amply shown by the accession of George III

${ }^{37}$ On these later editions and translations, see Giles G. Barber, "A Bibliography of Henry St. John, Viscount Bolingbroke" (B.Litt. thesis, Oxford University, 1963), pp. 215-21.

${ }^{38}$ Des devoirs d' un roi patriote, et portrait des ministres de tous les temps; ouvrage traduit de l'anglois de Bolingbroke, dedicated to 'Louis XVI, Premier Roi Patriote des François"' (Paris, 1790).

${ }^{39}$ Edward Lewis, The Patriot King Displayed: In the Life and Reign of Henry VIII. King of England (London, 1769), pp. 243-44 (Thomas Hollis presented a copy to the British Museum on 13 January 1769: BL 523.b.20).

${ }^{40}$ Charles Churchill, Gotham (London, 1764), bk. 3, lines 63-102, cited in Vincent Carretta, George III and the Satirists from Hogarth to Byron (Athens, Ga., 1990), pp. 4647.

${ }^{41}$ The Reign of George VI (London, 1763), p. 188; I. F. Clarke, Voices Prophesying War, 1763-1984 (Oxford, 1966), pp. 4-6; Gregory Claeys, ed., Utopias of the British Enlightenment, (Cambridge, 1994), p. xiv.

${ }^{42}$ I would therefore question John Guy's conclusion that the "rhetoric of counsel" became decisively "redundant" after the 1650 s as "a lexicon of rights and interests was 
in 1760, which in the eyes of radicals marked the beginnings of Georgian tyranny by a prince under the tutelage of Bolingbroke and his protégés. Bolingbroke had stressed that a patriot king should begin to rule as soon as he begins to reign and that monarchical accessions provided occasions for the application and evocation of patriot kingship. Horace Walpole circulated the charge that the new king had been educated in the principles of prerogative kingship, ${ }^{43}$ with Bolingbroke's work as his primer. However, as Herbert Butterfield and Romney Sedgwick showed some decades ago, these charges were not only baseless but could hardly have been more misplaced. ${ }^{44}$ The identification of George as a patriot king was first made not by those enemies who picked up the charge in the 1780 s but rather by his supporters, and he was most often later condemned for failing to live up to Bolingbroke's ideal, as, for example, by American colonists in the 1770s and by the dissenting historian William Belsham in his Memoirs of the Reign of George III (1795).$^{45}$ One of those who pressed on George the necessity of becoming a patriot king was James Burgh. In 1762, Burgh presented a mirror to his prince in the form of the manuscript "Remarks Historical and Political Collected from Books and Observations," with the express desire of encouraging him to be a reformist patriot king. ${ }^{46}$ That Burgh later became a leading proponent of parliamentary reform should not obscure the importance of this gesture, which indicates both the continuing afterlife of the Patriot King in radical circles of the 1760 s and the positive hopes invested in the work, before Walpole willfully tarred it as a textbook of tyranny. Nevertheless, Burgh had lost his faith in the court by 1774 . His advice book had gone unread, and his major work, Political Disquisitions - an encyclopedia of the Old Whig tradition from the seventeenth century onward-used extracts from Bolingbroke as a stick to beat the corrupted

recognized as more relevant to the discussion of liberty and authority" (John Guy, "The Rhetoric of Counsel in Early Modern England," in Tudor Political Culture, ed. Dale Hoak [Cambridge, 1995], p. 310).

${ }^{43}$ Horace Walpole, "A Memorial of Several Noblemen and Gentlemen of the First Rank and Fortunes" (1753), in Memoirs of King George II, 3 vols., ed. John Brooke (New Haven, Conn., 1985), 1:204-6, 3:163-65.

${ }^{44}$ Herbert Butterfield, George III and the Historians, rev. ed. (New York, 1959), pp. 231-37; Letters from George III to Lord Bute, 1756-1766, ed. Romney Sedgwick (London, 1939), pp. xix-xliii.

${ }^{45}$ William D. Liddle, " 'A Patriot King, or None': Lord Bolingbroke and the American Renunciation of George III,' Journal of American History 65 (1979): 951-70; William Belsham, Memoirs of the Reign of George III, 5 vols. (London, 1795), 1:3 (on the "perfect model of a PATRIOT KING, delineated by the happiest effort of a transcendent genius"); Butterfield, George III and the Historians, pp. 58-59, 234.

${ }^{46}$ James Burgh, "Remarks Historical and Political Collected from Books and Observations. Humbly Presented to the King's Most Excellent Majesty," 13 August 1762, BL, King's MS 433, fols. 86, 105. 
nation. ${ }^{47}$ There is no need, then, to propose that Burgh's career maps "the all-important transition from nostalgic opposition to progressive opposition" or that Burgh's progressivism represents the transcendence of Bolingbroke's supposedly reactionary nostalgia. ${ }^{48}$

The Idea of a Patriot King remained most influential as the locus classicus of blue-water theory and, in particular, of hostility to involvement in continental affairs. Bolingbroke portrayed the British as "like other amphibious animals," comfortable on land but more naturally sea creatures who could claim a natural security as island dwellers, even if this brought with it a responsibility not to intervene militarily in Europe: "But as we cannot be easily nor suddenly attacked, . . . we ought not to aim at any acquisition of territory on the continent." ${ }^{49}$ This isolationism had its intellectual roots in republican fears of territorial expansion in the $1650 \mathrm{~s}$, was reaffirmed during the standing army controversy of the $1690 \mathrm{~s},{ }^{50}$ and could still be found in the patriot dramas of the $1770 \mathrm{~s}$, which showed the impress of Bolingbroke's work. The Patriot King had sprung from the soil of patriot poetry and plays in the 1730s, and patriot kingship returned to the English stage in response to increased AngloIrish tension in the mid-1770s and to the possibility of Franco-Spanish attack during the American War. Francis Dobbs, the future associate of Henry Grattan, presented a Bolingbrokean argument against conquest in a dramatization of early Irish history entitled The Patriot King; Or, The Irish Chief (1774), ${ }^{51}$ while Alexander Bicknell's The Patriot King; Or,

${ }^{47}$ Dickinson, Bolingbroke, p. 307; James Burgh, Political Disquisitions: An Enquiry into Public Errors, Defects, and Abuses, 3 vols. (London, 1774-75), 1:78-79, 118, 12122 , 273-74, 371-72, 377; 2:45-47, 168-70, 456-57; 3:197, 282, 343, 361, 414, 44143.

${ }^{48}$ Isaac Kramnick, "James Burgh and 'Opposition' Ideology in England and America," in his Republicanism and Bourgeois Radicalism: Political Ideology in Late Eighteenth-Century England and America (Ithaca, N.Y., 1990), pp. 205, 206. Kramnick's account overlooks Burgh's "Remarks Historical and Political" entirely.

${ }^{49}$ The Idea of a Patriot King, in Armitage, ed., Bolingbroke: Political Writings, pp. 279, 277; Daniel A. Baugh, “'Great Britain's 'Blue-Water' Policy, 1689-1815,'” International History Review 10 (1988): 52-53.

${ }^{50}$ On the seventeenth century, see David Armitage, "John Milton: Poet against Empire," in Milton and Republicanism, ed. David Armitage, Armand Himy, and Quentin Skinner (Cambridge, 1995), pp. 207-10, 223-24; on the eighteenth-century arguments over the continental commitment, see Baugh, "Great Britain's 'Blue-Water' Policy"; Richard Pares, "American versus Continental Warfare, 1739-1763," English Historical Review 51 (1936): 429-65; N. A. M. Rodger, "The Continental Commitment in the Eighteenth Century," in War, Strategy, and International Politics: Essays in Honour of Sir Michael Howard, ed. Lawrence Freedman, Paul Hayes, and Robert O'Neill (Oxford, 1992), pp. 39-55.

${ }^{51}$ Francis Dobbs, The Patriot King; or the Irish Chief (London, 1774). On Dobbs, see A. T. Q. Stewart, A Deeper Silence: The Hidden Origins of the United Irishmen (London, 1993), pp. 36, 42-43, 45. 
Alfred and Elvida (1788), written in 1778 under the threat of FrancoSpanish invasion but not published until 1788 , pointedly showed the embattled forces of Alfred's Saxon England ranged against the pagan Danes led by King Haldane. The moral thrust of the play concerned the necessity of uniting "A patriot People, and a patriot King" for the defense of the island against invasion, not least to show that "Alfred's life to future Kings shall prove, / That their best safe-guard is their Subjects love." The play counseled defense rather than offense and denied the legitimacy of conquest. The message of the drama was not lost in radical circles, and such luminaries as Major John Cartwright, Thomas Brand Hollis, and John Sawbridge appeared on the subscription list. ${ }^{52}$

The Atlantic imperial crisis of the 1770s strained both the ideal of paternal kingship and the benign notion of commercial empire that had been evoked in Bolingbroke's vision of blue-water patriarchalism. ${ }^{53}$ The colonists who had praised George III for his Bolingbrokean qualities, at least up to 1774 (when Thomas Jefferson called the king to account in A Summary View of the Rights of British America), demanded "A patriot King, or none, over the British Colonies": instead, they found themselves in rebellion against Thomas Paine's "Royal Brute of Great Britain." 54 The critical year of 1775, which saw competing waves of petitions both for and against conciliation with the colonists, also generated a timely rewriting of Bolingbroke's advice to a prince as A Key for Kings: Integrity the Best Security: A Patriot King the Best Prince to Make a Nation Prosperous, and It's Government Firm and Lasting (1775). This cento of passages from The Idea of a Patriot King was published in Birmingham by the radical printer and newspaper-proprietor Myles Swinney and was intended not only as advice to King George but also as an intervention in the bitterly contested debate in the West Midlands over the justice of the colonists' cause and the response to their rebellion. ${ }^{55}$ The editor of the selection took the words from Bolingbroke's mouth and

${ }^{52}$ Alexander Bicknell, The Patriot King; or, Alfred and Elvida (London, 1788), pp. [iii], [vii], [iv]-vi, 67; Haydn composed incidental music for J. W. Cowmeadow's adaptation of Bicknell's play, Alfred, König der Angelsachsen, oder der patriotische König, in 1796. Alfred remained a patriot hero for all of the period surveyed here; cf. James Thomson, Alfred: A Masque (London, 1740); and James Sheridan Knowles, Alfred the Great; or, the Patriot King, dedicated to William IV, "A Patriot Monarch" (London, 1831).

${ }^{53}$ Eliga Hayden Gould, "War, Empire and the Language of State Formation: British Imperial Culture in the Age of the American Revolution"' (Ph.D. diss., Johns Hopkins University, 1993), chap. 3.

${ }^{54}$ Liddle, “' 'A Patriot King, or None,', " pp. 955-60, 964-65, 968.

${ }^{55}$ For Myles Swinney and his support of the colonists and the conciliatory petition of 1775, see John Money, Experience and Identity: Birmingham and the West Midlands, 1760-1800 (Manchester, 1977), p. 59. 
despaired for "the British Spirit . . . which has preserved Liberty hitherto" and thought, "Nothing can so surely and so effectually restore the Virtue, the Public Spirit, essential to the Preservation of Liberty, and National Prosperity, as the Reign of a Patriot King." ${ }^{56}$ Rather than reprint the whole of Bolingbroke's work, he pruned it back to those parts that emphasized the king's obligations to his subjects, his duty to uphold their liberty, the vulnerability of a corrupted people, and the king's place above party. Most pointedly, in view of the imperial crisis, he reminded the king that he must staunch "the phrenzy of rebellion" and "remember peace in the midst of war," for only he had the power to unite a divided people. Though the key passages that commend a blue-water policy were omitted, the work retained intact the closing pages that advised against expensive military action abroad and for the defense of the national interest without the cost of high taxation and national debt. ${ }^{57}$ Only then could Bolingbroke's triumphant concluding vision of prosperity with honor be achieved. As applied to the situation in 1775, the editor's messageconveyed through the skillful editing of Bolingbroke's words-was clear: only the king had the moral authority to arbitrate in the imperial dispute; a military solution to the conflict was against the public good; and Britain's greatest interest lay in retaining the integrity of the maritime empire, which could only be safeguarded by a conciliatory response to the colonists' demands.

As the American War dragged into its fourth grueling and costly year, patriot kingship was at the center of debate during the stormy meeting of the Yorkshire Association on the night of 30 December 1779. As the climax of the Association Movement, the York assembly was the curtain-raiser for what Butterfield famously described as Britain's "revolution that we escaped"' in 1780, the year of Dunning's Resolution, Burke's movement for Economical Reform, and the Gordon Riots. ${ }^{58}$ Though the expectation seems to have been that the meeting would be consensual, the intervention of one local notable was startling and raised a squall of controversy that blew well into 1780 . Leonard Smelt, the former subgovernor to the Prince of Wales and hence the suspected mouthpiece of the court, spoke out vehemently against the terms of the petition and argued that at such a time of crisis-with land war in America, disaffection in Ireland, the nation's defenses run-down, and the

\footnotetext{
${ }^{56}$ A Key for Kings: Integrity the Best Security: A Patriot King the Best Prince to Make a Nation Prosperous, and It's Government Firm and Lasting (Birmingham, 1775), p. iv.

${ }^{57}$ Ibid., pp. 17, 18-19, 24.

${ }^{58}$ Herbert Butterfield, George III, Lord North and the People, 1779-1780 (London, 1949), p. vi.
} 
people seemingly unconscious of their civic duty-the powers of the crown should actually be increased to help the nation resist the emergency. ${ }^{59}$ Smelt argued that the king could do no wrong, that it was the people who were corrupt, and that the king was not the servant of this selfish and supine populace but rather was "not only the first, the greatest, and the best, but, I am sorry to say it, . . . the ONLY Patriot in this Country." ${ }^{60}$ Smelt's remarks outraged his opponents. Christopher Wyvill and his supporters charged that Smelt spoke the language of the court and that these "revived doctrines of Toryism," in which the king had been raised, were in fact responsible for the loss of the colonies, national decline, and the collapse of Britain's international standing. ${ }^{61}$

Two warring versions of patriotism were arrayed in the debate over the Yorkshire Association meeting, the imperial and the oppositional. Smelt's speech was reported from both perspectives and nuanced accordingly. The competing versions exemplified the politicized reconstruction of speeches, inflected by precise agendas and directed to sympathetic audiences, that was characteristic of late eighteenth-century public prints. ${ }^{62}$ Smelt's own version of his speech stressed the honor of the crown - that dangerous prerogative at which his antagonists bridledand "the dignity of the empire . . . against the insidious attacks of the despotic house of Bourbon," and took a broad imperial perspective on the preceding century of British history. He blamed the Revolution Settlement and the Hanoverian succession for inducing complacency in Britain, allowing the Whigs systematically to foster selfishness and corruption, which all led to the death of amor patrice. He concluded with a warning for the whole empire. Once more, Britain was on the defensive against the French (who had allied with the rebellious colonists the year before). In this time of national danger that much needed amor patrice was reawakening. The common danger could at last help "to open the

${ }^{59}$ Ibid., pp. 202-4. The Wyvillites' version of Smelt's speech can be found in The Speech of Leonard Smelt, Esq. Delivered by Him at the Meeting of the County of York, December 30, 1779 (York, 1780), reprinted in Christopher Wyvill, Political Papers: Chiefly Respecting the Attempt of the County of York, and Other Considerable Districts, Commenced in 1779 and Continued during Several Subsequent Years, to Effect a Reformation of the Parliament of Great-Britain, 6 vols. (York, 1794-1804), 1:13-29 (for Wyvill's defense of this version of the speech, see 1:v-viii). Smelt replied in [Leonard Smelt], An Account of Some Particulars, Which Passed at the Meeting Held at York, on Thursday, the 30th December, 1779 (n.p., 1780). The speech was also paraphrased in The Yorkshire Question, or Petition, or Address (London, [1780]), pp. 13-17.

${ }^{60}$ The Speech of Leonard Smelt, pp. 13, 25, 26-27.

${ }^{61}$ The System Occasioned by the Speech of Leonard Smelt, Esq. (London, 1780), pp. $5,20$.

${ }^{62}$ Dror Wahrman, "Virtual Representation: Parliamentary Reporting and the Languages of Class in the 1790s," Past and Present, no. 136 (1992): 85-86, 89-91, 108. 
eyes of America to her true interest, and to effect a complete union of the whole empire under a common advantage, common liberty and common support." How foolish, then, to press for a divisive petition that would create domestic division, undermine patriotism, and enervate the imperial sovereignty of King George. ${ }^{63}$

Supporters of the crown demanded that patriotism should be reappropriated as an imperial virtue; to radical opponents of the court, this attempt to hijack amor patrice smacked above all of royal prerogative, Tory doctrine, and the "language of the court." The Wyvillites charged that Smelt had amply confirmed what had long been suspected: that there had been a plot for Georgian tyranny, inculcated by the king's tutors in his youth, affirmed at his accession, and enacted ever since in the expansion of the prerogative and the strengthening of the crown. Smelt had been a humble character in this plot, but the script had been written forty years earlier and soon all would be revealed: "It is thought . . . that when a certain Paper, which was written by the late Lord Bolingbroke, for the Use of the late Prince of Wales, appears, there will be found a perfect Consistency in the Measures of the last twenty Years; and that the Manuscript alluded to, and the Speech here published, will be thought a proper Prologue and Epilogue to the Drama, ... . which during that Period, has been uniformly playing on a certain Stage." ${ }^{64}$ The key terms in this drama were patriotism and kingship; the deepest divisions lay between a national and an imperial perspective on each. To Smelt, patriot kingship represented the only salvation for the empire when the people had been corrupted by self-interest and Whiggery. However, for the Wyvillites, such a vision of monarchy was simply the tempting bait for Georgian tyranny, a trap waiting to be sprung at a time of national emergency. The king could still rescue himself from that trap, advised Wyvill, but only by hearkening to the Yorkshire petition: "A patriot King must esteem himself happy in the opportunity it would afford him to gratify his subjects by redressing their just complaints." ${ }^{65}$ This appeal was to the patriot king as the father of his people rather than as an imperial monarch. The masks of Bolingbroke's character were beginning to break apart from one another, as the ideal of patriot kingship was becoming fitfully identified with a monarchy above Parliament rather than a monarch beyond party.

The battle over patriot kingship during the Association Movement showed what was at stake in the struggle for the language of patriotism

${ }^{63}$ [Smelt], An Account of Some Particulars, pp. 5-6, 10, 29-30.

${ }^{64}$ The Speech of Leonard Smelt, "Preface"' (unpaginated).

${ }^{65}$ Wyvill, Political Papers, 1:39. 
during and after the American War. For loyalists and royalists, there was the strength of the crown, the unity of the people in their allegiance to the monarchy, and an imperial vision that subsumed all citizens of the empire under that allegiance; for radicals, there was the fear that patriotism's only constituency could be the people, that the crown was its enemy, and that the unity of the empire could only be maintained at the expense of loss of liberty at home. As the recognition of American independence in 1783 revealed, Bolingbroke's benign blue-water vision of imperial patriotism was no longer sustainable in the more authoritarian empire, which was based on territorial expansion in the east, of the later eighteenth century. ${ }^{66}$ One reformist pamphleteer in 1783 recommended a patriot king as the annihilator of faction, "the real Friend and political Father of his Subjects," "the arbiter of Europe," and the restorer of Britain's "Empire of the Seas." By making this appeal, the author caught the temper of the times, when even reformism was cast in the conservative idiom of national unity and monarchical paternalism. ${ }^{67}$ However, Bolingbroke's posthumous association with metropolitan radicalism, the persistent myth that King George had been raised on his prerogative principles, and the collapse of imperial citizenship prevented the ideal of patriot kingship from playing any part in the reconstruction of the monarchy's image in the years after the loss of the American colonies. In parallel with the dethronement of the patriot king, "Rule, Britannia," that piece of blue-water triumphalism first performed before Frederick, Prince of Wales, in 1740, declined in popularity. Meanwhile, the xenophobic monarchical patriotism of the period was hailed with "God Save the King", as its anthem. ${ }^{68}$

The Idea of a Patriot King was not reprinted between 1783 and 1831 , and patriot kingship was only rarely called on in the intervening period. The patriot king rose one last time from the grave to haunt the proponents of war in July 1797. In a visionary version of the King's closing speech to the Parliament of $1796-97,{ }^{69}$ The Speech of a Patriot

${ }^{66}$ On the complexion of the late eighteenth-century empire, see esp. P. J. Marshall, "Empire and Authority in the Later Eighteenth Century,"' Imperial and Commonwealth History 15 (1987): 105-22; and C. A. Bayly, Imperial Meridian: The British Empire and the World, 1780-1830 (London, 1989), chap. 4.

${ }^{67}$ A Solemn Appeal to the Good Sense of the Nation: Pointing out the Immediate Necessity of a Cordial Coalition between the King and the People (London, 1783), pp. 12-14, 59; cf. Gould, "War, Empire and the Language of State Formation,"' pp. 25558.

${ }^{68}$ Colley, "The Apotheosis of George III," p. 104; see Thomson, Alfred: A Masque, pp. 42-43; and William Hayman Cummings, Dr. Arne and Rule Britannia (London, 1912), pp. 111-36.

${ }^{69}$ For George III's own speech, see The Parliamentary History of England from the Earliest Times to 1803, 36 vols. (London, 1806-20), vol. 33, cols. 854-55. 
King to His Parliament imagined George III as the peacemaker above party, determined to renovate the constitution, restore the nation's trade, reform Parliament and, if necessary, step down from his throne in favor of a republic, if that were the wish of the people. This phantasmal monarch proclaimed his disdain for stock-jobbing, speculation, and corruption; decried the necessity of a standing army, "that engine of Despotism, especially in a maritime country"; and warned against continental alliances. "These great points," concluded the imaginary ruler, "these essential measures for the protection of the Empire, I leave, my Lords and Gentlemen, to your deliberative wisdom; and, in doing so, I trust that I best fulfil the duties of a Patriot King." ${ }^{70}$ With such a fantasy, the patriot king had become a republican's dream, a feebly melancholic protest against the aggressive royalism of the war years. The patriot king had become "Romantic nonsense. A monster, a chimæra in politics, what never did and never will exist," and the dangers of philosophical intervention in the practical business of politics. "Utopia is a vision," Thomas Green argued. "The idea of a patriot King was never realized, and Bolingbroke often advanced what he did not mean." 72

The ideal of the patriot king was dissociated from Bolingbroke himself and-when invoked at all-became merely the coin of respectable opposition and traditional constructions of limited monarchy, as in Catharine Macaulay's entirely conventional recommendations for safeguarding the "patriotism of a king" through correct education as a prince. ${ }^{73}$ Typical of the conservative revanche of these years was the use of the patriot king as an anodyne defense of the British constitution in particular, and of monarchy in general (in company with Montesquieu, Sir William Blackstone, John Hampden, and the elder Pitt), but this necessitated stripping Bolingbroke's ideal of its polemic against corruption, its demands that the patriot king rise above party strife, and its blue-water policy. ${ }^{74}$ Even Burke, for all of his rather disingenuous scorn of Bolingbroke, could agree with the "presumptuous and superficial writer'" that a mon-

${ }^{70}$ The Speech of a Patriot King to His Parliament (London, 1797), pp. 7-8, 11-12, 14, 17-18, 19.

${ }^{71}$ Poetical Epistle from Florizel to Perdita: With Perdita's Answer. And a Preliminary Discourse upon the Education of Princes (London, 1781), p. 14.

72 [Thomas Green], Slight Observations upon Paine's Pamphlet: Principally Respecting His Comparison of the French and English Constitutions (London, 1791), pp. 4445 .

${ }^{73}$ Catharine Macaulay Graham, "Letter XXV: Hints towards the Education of a Prince," in her Letters on Education (London, 1790), pp. 223-34.

${ }^{74}$ Hints; to the People of England: For the Year 1793 (London, 1792), pp. 32-33. 
archy was preferable because of the constitutional flexibility it allowed. ${ }^{75}$ Yet, in the face of the French Revolution and the Revolutionary Wars, there is little sign that Bolingbrokean patriot kingship played any part in the reconstruction of Georgian kingship, except at the very end of George's reign as a counter to claims for Catholic emancipation and in celebration of the "efforts of a PATRIOT KING, under God," who had held back the deluge of "bad principles, bad morals and bad government" that had flooded post-Revolutionary Europe. ${ }^{76}$ This was patriot kingship as Smelt had conceived it and as his opponent had feared it: a conservative, Protestant, insular, and above all counterrevolutionary ideology that could be used, belatedly, in the effort to reappropriate patriotism for the monarchy and clear it of the "odious deformity" it had taken on by falling among radicals and reformers. ${ }^{77}$

Since The Idea of a Patriot King played little part in the apotheosis of George III and indeed did more to blacken his reputation in the Whig myth of Hanoverian tyranny, it is all the more remarkable that it did help the brief apotheosis of William IV. Bolingbroke had stressed the importance of the beginning of the patriot king's tenure of the throne: he should govern as soon as he begins to reign because "a Patriot King is the most powerful of all reformers. . . A new people will seem to arise with a new king." 78 The first year of William IV's reign saw an unprecedented application of these hopes to the new monarch, who was praised in pamphlets as a friend to reform and, because he dissolved Parliament in 1831, for putting himself above party and the thraldom of his ministers. ${ }^{79}$ Yet it was in making the best of William's blunt character and unusual naval upbringing that he showed himself most enduringly

${ }^{75}$ Edmund Burke, Reflections on the Revolution in France, ed. J. G. A. Pocock (Indianapolis, 1987), pp. 78 ("Who now reads Bolingbroke? Who ever read him through?"'), 110 (alluding to The Idea of a Patriot King, in Armitage, ed., Bolingbroke: Political Writings, pp. 230-31).

${ }^{76}$ The Patriot King . . . in which, the Claims of the Catholics are Legally, Equitably, and Liberally Considered (London, 1807), reprinted as The Patriot King; or, the Royal Rescue (London, 1808); Robert Humphreys, The Patriot King. A Sermon Preached . . . on the Occasion of the Jubilee Celebrated in Honour of the Fiftieth Anniversary of the Accession of His Majesty King George III to the Throne (Leeds, 1809), p. 22.

${ }^{77}$ The Patriot King ... in which, the Claims of the Catholics are Legally, Equitably, and Liberally Considered, p. $47 \mathrm{n}$. p. 251 .

${ }^{78}$ The Idea of a Patriot King, in Armitage, ed., Bolingbroke: Political Writings,

${ }^{79}$ See, e.g., [H. Bellenden Ker], The Patriot King to His People. Addressed to Every Elector of Great Britain (London, 1831); Britons! Support Your Patriot King and His Enlightened Ministers against an Unwise Faction, Whose Measures Would Lead to Revolution (London, 1831); Plain Reading for Plain People! Being an Account of the English Constitution; and the King's Reform Bill (London, 1831), p. 18. 
to have been a patriot king. Bolingbroke's three-faced king not only had to be a reformer and above party, but he had to show a commitment to Britain's maritime and commercial destiny. The two Georges, who had together presided over the loss of the American colonies, the territorial expansion of an increasingly authoritarian empire in Asia, and the continental commitments of the Revolutionary and Napoleonic Wars, had failed to uphold the most potent and achievable part of Bolingbroke's ideal. Yet William had entered public life as a sailor (not a soldier), had fought in the navy during the American War, and had promoted commerce as the national interest while Duke of Clarence in the House of Lords. On these grounds, John Watkins argued in the early biography, The Life and Times of "England's Patriot King," William the Fourth (1831), that William was indeed the long-awaited patriot king and that "What the masterly hand of BOLINGBROKE sketched as an ideal character and a vision of virtuous excellence, this nation happily enjoys in the reign of WILLIAM THE FOURTH." 80

William IV was probably the only monarch to have read Bolingbroke's work and to have taken his counsel. On the eve of the prorogation of Parliament to prevent a second rejection of the Reform Bill by the House of Lords, he retailed that advice to his prime minister, Earl Grey: "It is His Majesty's most anxious desire that all that can irritate should in future be avoided, and he does not know that he can better express his feelings on this occasion than by transcribing the words of Lord Bolingbroke, which appear to him peculiarly applicable: 'As every new modification in a scheme of government and of national policy is of great importance . . . the duty of a Prince seems to require that he should render by his influence the proceedings more orderly and deliberate, even when he approves the end to which they are directed.' ",81 Even in death these ideals were not disappointed, for he died (according to one funeral sermon) "a PATRIOT KING, and the FATHER OF HIS PEOPLE!" 82 Yet if William is remembered at all, it is not as the supporter of Catholic emancipation or the facilitator of Reform but rather as the "Sailor King" perhaps the one afterlife of Bolingbroke's ideal that still lingers in British historical memory.

${ }^{80}$ John Watkins, The Life and Times of "England's Patriot King," William the Fourth (London, 1831), pp. iii, 37, 350.

${ }^{81}$ William IV to Charles, Earl Grey, 17 October 1831, in The Reform Act, 1832: The Correspondence of the Late Earl Grey with His Majesty King William IV, and with Sir Herbert Taylor, ed. Henry, Earl Grey, 2 vols. (London, 1867), 1:381-82, citing The Idea of a Patriot King, in Armitage, ed., Bolingbroke: Political Writings, p. 260.

82 Thomas Frognall Dibdin, The Patriot King. A Sermon Preached . . . in Memory of His Late Most Gracious Majesty, William IV (London, 1837), p. 9. 
The Reform agitation of 1831 also supplied the context for the last republication of the Patriot King before the twentieth century. In that year, a new edition appeared with copious variorum notes, "Incorporated with Such Observations as May Render his Lordship's Principles and Precepts Subservient to Practical Use at this Momentous Crisis of Reform," and it may indeed have been from this edition that William himself took Bolingbroke's counsel, though its editor suspected some wellstocked ship's library had in fact supplied the king with "his political bible." ${ }^{83}$ The Bolingbrokean utopia imagined in the 1730s might now be realized in the 1830 s, with a patriot king on the throne and a politically active-and hence, in Bolingbrokean terms, virtuous-people soon to be enfranchised through the mechanism of parliamentary reform. The "Reformed Whig"' who edited the work for its new audience placed himself and Bolingbroke in an eclectic line of patriots that extended from the commonwealthmen of the seventeenth century, through the Whigs of the eighteenth, to the participants in the Revolution controversy (including both Paine and Burke), though he, like many later commentators, was cautious in his assessment of Bolingbroke's ambivalent relation to this tradition. He was clearly uneasy about his author's reputation and reformist credentials and urged his audience to discriminate "when the sound social philosopher, maintains a due ascendency $[\mathrm{sic}]$ over the Tory viscount." $" 84$

The question whether Bolingbroke should be seen as a "sound social philosopher" or "the Tory viscount" has been decided by reductionist historians in favor of the latter. This is testimony to the success of Disraeli and the Young England Movement in making Bolingbroke into a prescriptivist and Burkean avant la lettre, who could be drafted in to deny that the Reform Act had changed anything at all in Disraeli's Vindication of the English Constitution (1835) ${ }^{85}$ The Young England reading of Bolingbroke has held the ring ever since. The Bolingbroke whom Disraeli called on as a critic of the "Venetian oligarchy" of the great Whig families, the threnodist of a lost organic agrarian polity, and the proponent of the rule of a natural aristocracy remains the prevalent account of the social philosopher as nostalgic, antidemocratic, and reactionary-

${ }^{83}$ The Patriot King; and, an Essay on the Spirit of Patriotism, by Lord Viscount Bolingbroke . . . Including a Dissertation on the English Constitution, by a Reformed Whig (London, 1831), pp. 164-65. The publisher of this edition, John Brooks, also reprinted Thomas Paine's Common Sense: The Crisis (London, 1831) as an intervention in the Reform debate.

${ }^{84}$ The Patriot King; and, an Essay on the Spirit of Patriotism, pp. 11, 149.

${ }^{85}$ Benjamin Disraeli, Vindication of the English Constitution in a Letter to a Noble and Learned Lord (London, 1835), pp. 185-88; Faber, Beaconsfield and Bolingbroke, pp. 29-37. 
in short, as everything one might expect of a Tory and a viscount. Yet this is not the Bolingbroke whom the American rebels of the 1770s, the petitioners of 1775, the English radicals of the 1780s, or the supporters of Reform in the 1830s would have recognized, not least because it is Bolingbroke without the patriot king. The Patriot King had been too imprecise to provide useful counsel in the 1730s, and its recipient in no position to act on it even if he read it. The work's utopian aspiration, which was nonetheless so firmly grounded in Britain's interests and circumstances, allowed for flexibility in its application throughout the eighteenth century. Yet what is most suggestive in the afterlife of the Patriot King is how little it contributed to the loyalism and royalism that were deployed against radical patriotism in the reign of George III. The transfer of the language of patriotism "from the English radicals to the British state," ${ }^{86}$ which occurred during these years, had the effect, a generation later, of delivering up Bolingbroke from the hands of the radicals to the embrace of conservatives, with whom he remains to this day. No longer a patriot for all, as Bolingbroke hoped, the patriot king would thenceforth be remembered, if at all, as a patriot only for some.

${ }^{86}$ Linda Colley, "Radical Patriotism in Eighteenth-Century England," in Samuel, ed., Patriotism, p. 184. 